\title{
LITURGICAL ANAMNESIS AS AN ELEMENT OF THE EUCHOLOGY OF THE MASS
}

DOI: http://dx.doi.org/10.12775/TiCz.2021.015

\begin{abstract}
In modern liturgical theology, the concept of "anamnesis" has become a dominant feature that defines the liturgy. Without understanding the essence of anamnesis, it is impossible to grasp the essence of the Christian liturgy. In other words, without anamnesis, the liturgy would not be liturgy. Liturgical anamnesis is, above all, an objective remembrance and actualization hic et nunc of the Paschal Mystery of Christ. It is a reminder of the past, but also an anticipation of the salvific future and the heavenly liturgy. In a narrower sense, the anamnesis is an integral part of the Christian euchology. This paper presents the latter understanding of the word "anamnesis" as a formal element in the structure of the euchology that recalls not only the different stages and facts of Christ's life, but also the entire history of salvation in both a theological and a chronological sense.
\end{abstract}

Keywords: anamnesis; Eucharist; euchology; Paschal Mystery.

Streszczenie. Anamneza liturgiczna jako element euchologii mszalnej. Pojęcie „anamnezy” stało się we współczesnej teologii liturgii dominantą określającą liturgię. Bez zrozumienia istoty anamnezy nie można zrozumieć istoty liturgii chrześcijańskiej. Innymi słowy, bez anamnezy liturgia nie byłaby liturgią. Anamneza w liturgii jest przede wszystkim obiektywnym wspominaniem i aktualizowaniem hic et nunc Misterium Paschalnego Chrystusa. Jest pamiątką przeszłości, ale i antycypacją zbawczej przyszłości i liturgii niebiańskiej. Natomiast w sensie węższym anamneza stanowi integralną część euchologii chrześcijańskiej. W opracowaniu przedstawiono anamnezę w tym dru- 
gim znaczeniu: jako formalny element w strukturze euchologii, wspominający nie tylko poszczególne etapy i fakty z życia Chrystusa, lecz także całą historię zbawienia zarówno w sensie teologicznym, jak i chronologicznym.

Słowa kluczowe: anamneza; Eucharystia; euchologia; Misterium Paschalne.

\section{INTRODUCTION}

In modern liturgical theology, the concept of "anamnesis" has become a dominant feature that defines the liturgy. ${ }^{1}$ Without understanding the essence of anamnesis, it is impossible to grasp the essence of the Christian liturgy. Anamnesis is a fundamental category of the liturgy: without it, the liturgy would not be liturgy. ${ }^{2}$

Liturgical anamnesis ontically transcends the human being as a subject that understands and acts. It is an objective remembrance and actualization hic et nunc of the Paschal Mystery of Christ, an objective reminder of the past, but also an anticipation of the salvific future and the heavenly liturgy; it is something impossible - and in fact incomprehensible - for a human being, but feasible for God. Even though the salvif-

1 See W. Świerzawski, “Odo Casel (1886-1948) - życie i dzieło,” Ruch Biblijny i Liturgiczny 41 (1988) 2, p. 95. In recent decades, the question of anamnesis in the liturgy has featured ever more prominently as the subject of in-depth studies and symposiums. In this context, one may refer to the deliberations of the 56th Liturgical Week, which took place in Paris in 2009 and resulted in the publication of the papers contained in "Faire mémoire": l'anamnèse dans la liturgie. Conférences Saint-Serge LVI Semaine d'Études Liturgiques. Paris 29 juin - 2 juillet 2009, ed. A. Lossky and M. Sodi, Vatican City 2011.

2 Cf. B. Nadolski, Chwała Ojcu. Doksologie w liturgii, Poznań 1999, pp. 10-11. The term "anamnesis" comes from the Greek word anàmnesis (Latin: memoriale, memoria) and etymologically means "recollection," "remembrance," "reminder," "rediscovery of one's existing knowledge" or "reminiscence." Some dictionaries and encyclopedias (especially those of a more general nature) relate the term "anamnesis" exclusively to the history of philosophy and to medicine, or possibly to psychology. In the first sense, "anamnesis" is explained as a Platonic recalling of what one came to understand in the past, being in the world of ideas. In other words, "anamnesis" occurs when the soul "recalls" an idea that it had witnessed before "entering" the body of a specific human being. In the second sense, the word "anamnesis" means taking a patient's medical history, which is a basic step in the diagnostic process. According to the majority of the sources, the corresponding adnominal adjective is "anamnestic," however in liturgical theology, the commonly accepted term is "anamnetic." 
ic events that we celebrate every day - especially in the Eucharist - took place only once in specific spatiotemporal circumstances, and historically have never reoccurred and will not reoccur, thanks to the presence and action of the Holy Spirit they become present today in a sacramental manner every time they are celebrated (by Christ and by the whole Church) in the liturgy: in mysterio. This anamnetic dimension of the Christian liturgy constitutes its deepest historico-salvific sense, because the central element of the liturgy is the real presence therein of the entire Paschal Mystery of Christ and the entire history of salvation in mysterio. ${ }^{3}$

In a narrower sense, the anamnesis is an integral and essential part of the Christian euchology. ${ }^{4}$ In this paper, we are addressing this exact understanding of the anamnesis as a formal element in the structure of the euchology. ${ }^{5}$ And while - for methodological reasons - we will only address the anamnesis as an element of the liturgy of the Holy Mass, one must not forget that even in this narrower sense, the anamnesis cannot be associated with the liturgy of the Eucharist alone, or even exclusively with the Eucharistic Prayer, not can it be associated only with the remembrance of the key stages of the Paschal Mystery that takes place in this

3 The anamnesis of the Mystery of Christ in the liturgy precludes any attempts to narrow it to a purely psychological or mental - and therefore subjective - remembrance of salvific events, both past and future. Liturgical celebrations are an objective reminiscence that is independent of the human being, together with its salvific kairós in which Christ is present and acts "here" and "now." Liturgical anamnesis differs in its essence not only from the understanding of anamnesis as a subjective "recollection" in Platonism and Neo-Platonism, but also from Saint Augustine's concept of anamnesis and from the understanding of anamnesis in the modern nativist theory (which is related to Augustinianism). Anamnesis in the liturgy, despite there being many analogies and similarities, is also different from the anamnesis sometimes proposed as a method in catechesis. Furthermore, anamnesis in the Christian liturgy is ontically different from the "anamnesis" present in the ancient mystery religions, although in this case, one might speak of a formal (and only formal) analogy between the understanding of anamnesis in the known mystery cults and in the liturgy; see D. Brzeziński, "Chrystus wczoraj i dziś, i na wieki". Anamnetyczny wymiar roku liturgicznego, Toruń 2015, pp. 25-112; idem, "Human Dimension of the Christian Liturgy," Teologia i Człowiek 48 (2019) 4, pp. 73-77.

${ }^{4}$ Cf. M. Augé, "Eucologia," in: Nuovo Dizionario di Liturgia, ed. D. Sartore and A. M. Triacca, Cinisello Balsamo 1990, p. 512.

${ }^{5}$ Cf. D. Brzeziński, "Chrystus wczoraj i dzis", pp. 229-235. This text has served as a basis for the present paper. 
prayer - following the narrative of the institution of the Eucharist and the words of the consecration. ${ }^{6}$

\section{GENERAL CHARACTERISTICS OF THE ANAMNESIS IN THE EUCHOLOGY}

The anamnesis as an element of the Christian euchology, often drawing from the Old Testament berakhot, is a God-worshipping remembrance of salvific events. The outward graphical form of this remembrance consists in the texts written in liturgical books, whereas the verbal form consists in the corresponding words spoken by the celebrant (or celebrants) of the liturgy. ${ }^{7}$

The view that the Christian Eucharistic Prayers trace their origins to the Jewish berakhot, and therefore that the anamnesis they contain is modeled after the anamnesis that forms an integral part of the berakhot, was first presented by J. P. Audet at the International Congress of the Four Gospels in Oxford in 1957. ${ }^{8}$ In more recent times, among all the berakhot, the birkat hamazon (the blessing of the food) began to be noted as being particularly akin to Christian anaphoras. ${ }^{9}$ Soon afterwards, L. Bouyer also pointed to other types of berakhot, including those associated with the recitation of the Shema and the Tefillah. ${ }^{10}$

Although a liturgical anamnesis in its narrower sense (besides its primary meaning as the manner in which the Mystery of Christ is present

6 There is also an anamnetic dimension to the prayers associated with the celebration of sacraments and sacramentals other than the Eucharist, which portray the different aspects of God's presence and intervention in the history of the salvation of man and the world.

7 Cf. M. Augé, “Eucologia,” p. 512.

${ }^{8}$ Cf. J. P. Audet, "Literary Forms and Contents of a Normal Eucharistia in the First Century," Studia Evangelica 1 (1959), pp. 643-662; idem, "Esquisse historique du gentre litteraire de la 'bénédiction' juive et l'Eucharistie chrétienne," Revue Biblique 65 (1958), pp. 371-399; L. Bouyer, Eucaristia. Teologia e spiritualità della Preghiera eucaristica, Leumann 1992, pp. 101-144.

9 The Eucharistic Prayer is predominantly called an "anaphora" (meaning "prayer of the offerings" from the Greek anaphoreo - "to offer") in the Eastern liturgies. The term is used in reference to the Western Eucharistic Prayers per analogiam.

10 See L. Bouyer, Eucaristia, pp. 41-100; P. Vinsentin, "Eucaristia," in: Nuovo Dizionario di Liturgia, p. 486; P. F. Bradshaw, Alle origini del culto cristiano. Fonti e metodi per lo studio della liturgia dei primi secoli, Vatican City 2007, pp. 137-166. 
and as the reality that determines the ontic identity of the liturgy) - understood as the salvific events being commemorated in the liturgy and contained in the euchology - distinctively recalls only certain facts of Christ's life, it nevertheless celebrates Christ's entire story: all stages of His Paschal Mystery and of God's complete eternal plan that culminated in the gift of Himself given by Christ to the Father in exchange for the life of the world (cf. Hebrews 9:14). The anamnesis recalls the entire history of the world's salvation in a chronological and theological sense: all the things that God has done, is now doing and will do in the future for the salvation of man and of the world.

The anamnesis in liturgical celebrations always contains the entire Mystery of Christ: from Incarnation and Nativity (or, in fact, from the beginning of the world, when the fulfilment of God's eternal plan of salvation began) all the way to the Ascension, the Pentecost and the Second Coming.

All liturgical celebrations - in their anamnetic dimension - are interdependent. Each celebration expresses a certain aspect of the one and only Mystery of Christ, always present and undivided. The liturgical celebrations do not divide the unity of the Paschal Mystery, and none of the mysteries being celebrated can be comprehended without reference to the Paschal Mystery of the Son of God.

The liturgy celebrates Christ's presence in His unique Mystery that comprises different salvific aspects, moments and events; it celebrates the Mystery of Christ in His mysteries. The same also applies to celebrations for the Virgin Mary, the angels and the saints and blesseds, which would not be substantiated if they were to be separated from the salvific mysteries of the life of Jesus. The Mother of God as well as the angels, Apostles, martyrs and followers are all venerated in the Church due to their close association with the Paschal Mystery of Christ and to their unique participation in the life and work of the Savior and in the entire economy of salvation.

What took place in "that time" of the historic salvific events is simultaneously the liturgical present. Therefore, during liturgical celebrations which have an anamnetic dimension, we become the witnesses, partakers and celebrants of the events of the Paschal Mystery. Liturgical time is marked with the present ("right now") of God's salvation and with God's 
salvific presence that is being fulfilled "right now." In the liturgy, there is no difference between in illo tempore and hodie. Christ's Paschal Mystery has crushed the structure of worldly chronology. It is in the euchology that the "today" is very often emphasized. ${ }^{11}$

\section{ANAMNESIS AS AN ELEMENT OF THE MAJOR EUCHOLOGY}

A more or less extended anamnesis is present in all anaphoras, both Eastern and Western. ${ }^{12}$ Furthermore, in the Missal of Paul VI, anamnetic acclamations of the congregation were included after the transubstantiation to express gratitude for the work of salvation - as was the case with non-Roman (and in particular Eastern) liturgies; these had not been present until the publication of the new Ordo Missae in 1969, which immediately preceded the promulgation of the post-conciliar Roman altar missal. ${ }^{13}$

There is an anamnetic dimension to every preface in the Mass (called a "theological prayer" in the Eastern liturgies), and especially to the so-called embolism of the preface, which - by indicating the specific motive of thanksgiving in a given Mass - lists the mirabilia Dei.

If the Eucharistic Prayer is considered in isolation from the preface (which is possible, for example, in the Roman Canon, which does

11 See D. Brzeziński, "The Salvific Dimension of Time in the Christian Liturgy," Verbum Vitae 38 (2020) 1, pp. 340-342.

12 Here, we would like to refer the reader to the fundamental anthology of the earliest Christian anaphoras (in the Eastern and Western liturgies): Prex Eucharistica. Textus e variis liturgiis antiquioribus selecti, ed. A. Hänggi and I. Pahl, Fribourg 1968, p. 101-513. This critical edition of the texts is accompanied by a commentary and a list of key literature on the subject. See also: V. Trapani, Memoriale di salvezza. L'anamnesi eucaristica nelle anafore d'Oriente e d'Occidente, Vatican City 2006 (together with the relevant literature on the subject); Liturgia eucaristica bizantina, ed. M. B. Artioli, Turin 1988; A. Catella and G. Cavagnoli, Le preghiere eucaristiche. Analisi dei contenuti e indicazioni catechistiche, Cinisello Balsamo 1989; E. Mazza, Lanafora eucaristica. Studi sulle origini, Rome 1992; idem, Dall'Ultima Cena all'Eucaristia della Chiesa, Bologna 2014, especially pp. 107-246 (the author also offers a list of relevant literature on both Eastern and Western anaphoras).

${ }^{13}$ For a broader discussion of this subject, see C. Krakowiak, "Aklamacje anamnetyczne po konsekracji," in: Modlitwy Eucharystyczne Mszału Rzymskiego. Dzieje - teologia - liturgia, ed. H. J. Sobeczko, Opole 2005, pp. 167-179. 
not have a fixed preface, or in the Third Eucharistic Prayer), then one can say - in a certain simplification, of course - that the anamnesis (as an important piece of the eucharistic celebration) follows and remains in a close relationship with the description of the institution of the Eucharist. The transition between these two elements, that is between the words of the consecration and the anamnesis, may occur in two different ways. In that sense, one could speak of two types of anamnesis, as noted by B. Botte. The first one, the Syrian type, uses the very word anàmnesis in its personal or participial form ("we remember" or "remembering") in accordance with Luke's account (Luke 22:19). This type of anamnesis appears in the Gallican and Hispanic Rites as well as in the Roman Canon (unde et memores) and in the new eucharistic prayers contained in the Missal of Paul VI. The second type, known as the Alexandrian type, uses the term katangellein from Paul's First Epistle to the Corinthians (1 Corinthians 11:26). ${ }^{14}$

In the case of the Eastern anaphoras and the modern Roman Eucharistic Prayers with fixed prefaces (with the exception of the Second Eucharistic Prayer, which can be said with a different preface), to disregard the prefaces would be a significant omission and excessive simplification in any theologico-liturgical reflection on the anamnetic dimension of the liturgy.

Anamnesis in the form said after the words of the consecration is a remembrance and celebrative proclamation of the passion, death, resurrection and ascension of the Lord (or, in some cases, only His passion and death; the ascension has been included in the anamnesis in the Christian

14 The anamnesis (and epiclesis) were also adopted as a criterion in the classification of anaphoras (based on the placement of the epiclesis over the gifts in the structure of the Eucharistic Prayer) by the Italian liturgist C. Giraudo. In that respect, he distinguishes between anaphoras with an "anamnetic dynamic" (in which the epiclesis follows the narrative of the institution and the anamnesis) and anaphoras with an "epicletic dynamic" (where the epiclesis over the gifts precedes the narrative of the institution and the anamnesis), broadly analyzing the two types in terms of both formal aspects and content. According to Giraudo, anamnetic anaphoras include the anaphora of the Apostolic Constitutions and the anaphoras of Saint James, Saint Basil and Saint John Chrysostom; see C. Giraudo, Eucaristia per la Chiesa. Prospettive teologiche sull'eucaristia a partire dalla "lex orandi", Rome-Brescia 1989, pp. 383-452; cf. P. Nowakowski, "Anafory - modlitwy eucharystyczne Kościołów Wschodnich,” in: Modlitwy Eucharystyczne, pp. 7-23. 
liturgies since the fourth century).${ }^{15}$ And by taking an integral look at the Eucharistic Prayer, one finds that the anamnesis contains the entire spectrum of the Paschal Mystery of Christ and is therefore not limited to the final stage of Christ's earthly life. In that manner, the celebration of the Eucharist (and, more broadly, of the liturgy) becomes tantamount to the preaching and making present of the entire Paschal Mystery of Christ and the entire history of salvation.

It is worth adding that most of the Eastern anaphoras proclaim the exaltation of Christ to the right hand of God and the final advent of the Lord on the day of the Second Coming. Following their model, the Third and Fourth Eucharistic Prayers of the post-conciliar Roman liturgy also contain these eschatological elements, with the anamnesis of the Fourth Eucharistic Prayer in the Missal of Paul VI being the most elaborate and rich in content. The Mirabilia Dei that occurred throughout the history of salvation are mentioned as early as in the Post Sanctus and in the socalled "Christological prayer" (which follows the Sanctus, but precedes the narrative of the institution) that forms part of the Antiochene anaphoras, which include the Byzantine anaphoras of Saint James, Saint Basil and Saint John Chrysostom. ${ }^{16}$

15 As an example, we would like to make note of the "ranges" of mysteries from the life of Jesus mentioned in certain anaphoras. And thus, Christ's death (or passion alone) is remembered in the Syrian Liturgy of Saint John the Evangelist, the Gallican Rite and the Hispanic-Visigothic Rite. Christ's death and resurrection are remembered in the Syro-Antiochian anaphora of the Testamentum Domini and the Syro-Malabar anaphora of Addai and Mari. An anamnesis of the death, resurrection and ascension of the Lord is contained in the Roman Canon, in the Coptic Liturgy of Saint Mark and in the Eucharistic Prayer of Saint Ambrose's treatise De sacramentis. The death, resurrection, ascension and second coming of Christ are remembered in the "Clementine Mass" of the Apostolic Constitutions, the Liturgy of Saint Basil, the Liturgy of Saint John Chrysostom, the Liturgy of Saint Mark and the Ambrosian Rite. And finally, the anaphora of Saint John Chrysostom in the Ethiopian Church (which is an anaphora of the Alexandrian type) contains a liturgical lamentation of Christ in the form of an anamnesis; cf. W. Swierzawski, $D y$ namiczna "Pamiatka" Pana. Eucharystyczna anamneza Misterium Paschalnego i jego egzystencjalna dynamika, Kraków 1980, p. 223.

16 Cf. J. O. Braganca, "Struktura Modlitwy Eucharystycznej," Communio 1 (1986), pp. 263-264; J. Nowak, "IV Modlitwa Eucharystyczna," in: H. J. Sobeczko (ed.), Modlitwy Eucharystyczne, pp. 235-243. In the Mozarabic Rite, the equivalent of the anamnesis that follows the narrative of the institution is Post Pridie, and in the Gallican Rite, the Post Mysterium or Post Secreta. In these liturgies, there are many anaphoras for the different 
According to L. Ligier, this type of anamnesis includes all Old Testament blessings in which God is proclaimed to be blessed on account of His gracious gifts or miracles. Such anamneses are present in the anaphora of the Apostolic Tradition and the anaphora of the "Clementine Mass" in the Apostolic Constitutions. ${ }^{17}$

\section{ANAMNESIS AS AN ELEMENT OF THE MINOR EUCHOLOGY}

While anamnesis is, above all, part of the collect (Collecta), in some formularies it may also be present in the prayer over the gifts ( $\mathrm{Su}$ per Oblata), and sometimes in the post-Communion prayer (Post Communionem).

Among collects, two types can be distinguished: simple prayers and extended prayers. A simple collect begins with the invocation and progresses straight into the petition. Sometimes, it contains two petitions with a short invocation to God incorporated into the prayer. A simple collect does not contain an anamnesis.

Extended collects, on the other hand, have an elaborate literary form, and their structural parts are more developed. In the compositional structure of extended Roman collects and ordination prayers (e.g. the sacrament of the Holy Orders) and many blessings, beginning in the Christian antiquity, the following scheme was essentially established: anaclesis (invocation directed to God), anamnesis (remembrance of the great salvific works of God), petition, conclusion and the acclamatory Amen. ${ }^{18}$

The anaclesis (from the Greek anakalein - "to call," "to invoke") that opens the collect, spoken after the call to prayer (Oremus) and the moment of silence that follows, is an invocation that is typically expressed in the simple call Deus (in the so-called pure or classical Roman liturgy), or

days and celebrations of the liturgical year; see M. Augé, Introduzione alle liturgie occidentali, Rome 1992, pp. 40-41, 66-69.

${ }^{17}$ In the Syrian anaphoras of this type, the prayer is sometimes directed explicitly to the Son; see M. Olszewski, "Anamneza w liturgii bizantyjskiej," in: Mszał ksiega życia chrześcijańskiego, ed. B. Nadolski, Poznań 1989, p. 393.

${ }^{18}$ See H. B. Meyer, "Anamnese (5), Liturgisch," in: Lexikon für Theologie und Kirche, ed. W. Kasper et al., vol. 1, Freiburg-Basel-Wien 2009, col. 592. 
in the case of Roman-Germanic (Gallican) collects, in the words: Omnipotens sempitérne Deus or Clementíssime Deus, etc.

In the classical Roman collect, the anaclesis is followed by an anamnesis understood as a brief remembrance of God's works accomplished in the history of salvation, which varies depending on the liturgical celebration and invokes a single aspect of the Paschal Mystery. The anamnesis begins after the following phrase: Deus, qui... ("God, who [has done, caused...]"). The anamnesis is a fundamental component of an extended collect, a component which not only connects the past to the present and to the future, but also revives hope among those gathered at the liturgy and provides the assurance that the petition raised after the anamnesis will be heard. The content of the latter is internally connected with the anamnesis and with the mysteries being recalled in it.

Nowadays, the conclusion of the collect always takes an extended form that varies depending on whether the collect is directed to the Father (as is the classical way) or to Christ. The final Amen is an affirmation, a confirmation of and identification with the prayer that has been said on the part of all the celebrants and partakers of the liturgy.

The anamnesis of the collect expresses the character and content of the liturgical celebration. This is evident in the proper prefaces of any given celebration and, above all, in the collects of the major solemnities and feast days that commemorate historical salvific events. On the days on which the Church does not celebrate a specific event in the history of salvation, the collect refers - in its anamnetic layer - to the liturgical period and brings the petition to God within that context. During the Ordinary Time, collects reveal a certain aspect of God's Mystery and proceed into petitions for spiritual gifts for the faithful. During celebrations for the Virgin Mary, the angels and the saints, the anamnesis of the collect points to their participation in the Paschal Mystery of Christ and in the entire history of salvation. ${ }^{19}$

It needs to be emphasized that an anamnesis is also present in the collects of "idea feasts," that is feasts which refer not so much to historic salvific events as to salvation itself, notwithstanding the economy of salvation. These "idea feasts" - mainly stemming from a dogmatic reflection

19 Cf. J. Miazek, “Kolekta," in: Mszał księga życia, pp. 24-30. 
on the Revelation - are in a way "secondary" celebrations in relation to the major early Christian feasts that relate directly to salvific events and act as pillars of the liturgical year. Their development is dated to as late as the twelfth century. ${ }^{20}$ It has to be noted, however, that the Paschal Mystery of Christ - despite certain classificational "stereotypes" having been adopted - is the ultimate object of the anamnesis, and this applies to celebrations which are generally considered "idea feasts" as well. The "pre-foundation" of these celebrations is also God's historical, salvific intervention in the human spacetime.

Anamnetic references to the mystery of salvation being celebrated can also be found in prayers over the gifts and post-Communion prayers. However, they are rarer than in the case of collects and mainly concern solemnities and feasts or the "strong times" of the liturgical year. In formularies for the Blessed Virgin Mary and the saints, the anamnesis - as in the collects - portrays their imitation of Christ's life and death as well as the part they played in the history of salvation.

Therefore, one must not forget that while the prayer over the gifts primarily explains the act of offering the gifts of bread and wine (which come from God and are offered to Him), indicates the purpose of the gifts (which are to become the Body and Blood of Christ) and underlines the necessity of a spiritual sacrifice on the part of those offering the gifts, it nevertheless shows - in many cases - the relationship between the gifts and the spiritual sacrifice being offered on the one part and the mystery being celebrated and the salvific event being remembered on the other. ${ }^{21}$

The case is similar with the post-Communion prayer. It contains, first and foremost, a petition that the fruits of the Eucharist we have received persist in us and that we are led to participation in the glory of Heaven. On many occasions, however, this petition is tightly connected with the heortological context of a given celebration. This can clearly be seen in the oldest formularies of the Mass, where the post-Communion

${ }^{20}$ In his juxtaposition of "historico-salvific feasts" with "idea feasts," M. Kunzler asserts that the latter "lack an anamnetic element." It is difficult to agree with this - as it seems - exceedingly univocal opinion, although in the case of "idea feasts," the presence of such an element may not be immediately obvious, thus requiring some reflection to be "uncovered"; cf. M. Kunzler, Liturgia Kościoła, Poznań 1999, pp. 606-608.

${ }^{21}$ See J. Janicki, Modlitwy nad darami, in: Mszał księga życia, pp. 35-70. 
prayer has a more conclusive rather than communional character - as suggested even by the very description of the prayer as Ad complendum or Ad completa. ${ }^{22}$

\section{CONCLUSION}

The ultimate point of reference for all Christian celebrations is the Paschal Mystery of Christ in all its complexity and multifacetedness. The anamnesis in the euchology continually reminds and informs those taking part in the liturgy of that fact.

An anamnesis understood as a component of the euchology explains (within the meaning of explicat) in a simple and concise wording the anamnetic essence of the liturgy that contains a supernatural reality in mysterio. ${ }^{23}$ It is an epicletic prayer of worship that invokes God's "recalling, remembrance, memory" of his covenant and the promises of that covenant; a prayer through which salvific acts and promises are actualized for the celebrating community. ${ }^{24}$

The verbal expression of the anamnesis in the euchology is accompanied by a privileged linguistic form of invocation of the name of God: the hymnic participial style. In accordance with the biblical and theological sense of the liturgical anamnesis, God's past salvific acts are ascribed to Him in a participial form, and thus in a form that signifies the present state. The Roman prayers further expand upon the participial invocation of God's name in narrative relative clauses whose content returns in pleadings that concern the eschatic future. ${ }^{25}$

${ }^{22}$ See H. J. Sobeczko, Teologiczna treść modlitw pokomunijnych w nowym mszale, in: Mszat ksiegga życia, pp. 119-134.

23 Cf. W. Świerzawski, Dynamiczna "Pamiątka" Pana, p. 219.

24 B. Nadolski, Leksykon liturgii, Poznań 2006, p. 89.

25 See R. Schaeffler, "Przypomnienie/Anamneza," in: Leksykon religii. Zjawiska dzieje - idee, ed. P. Pachciarek, Warsaw 1997, p. 370-371. 


\section{BIBLIOGRAPHY}

Audet J. P., “Esquisse historique du gentre litteraire de la 'bénédiction' juive et l'Eucharistie chrétienne," Revue Biblique 65 (1958), pp. 371-399.

Audet J. P., "Literary Forms and Contents of a Normal Eucharistia in the First Century," Studia Evangelica 1 (1959), pp. 643-662.

Augé M., "Eucologia," in: Nuovo Dizionario di Liturgia, ed. D. Sartore and A. M. Triacca, Cinisello Balsamo 1990, pp. 509-519.

Augé M., Introduzione alle liturgie occidentali, Rome 1992.

Bouyer L., Eucaristia. Teologia e spiritualità della Preghiera eucaristica, Leumann 1992.

Bradshaw P. F., Alle origini del culto cristiano. Fonti e metodi per lo studio della liturgia dei primi secoli, Vatican City 2007.

Braganca J. O., "Struktura Modlitwy Eucharystycznej," Communio 1 (1986), pp. 255-268.

Brzeziński D., "Chrystus wczoraj i dziś, i na wieki”. Anamnetyczny wymiar roku liturgicznego, Toruń 2015.

Brzeziński D., "Human Dimension of the Christian Liturgy," Teologia i Człowiek 48 (2019) 4, pp. 71-89.

Brzeziński D., "The Salvific Dimension of Time in the Christian Liturgy," Verbum Vitae 38 (2020) 1, pp. 329-351.

Catella A. and Cavagnoli G., Le preghiere eucaristiche. Analisi dei contenuti e indicazioni catechistiche, Cinisello Balsamo 1989.

"Faire mémoire". L'anamnèse dans la liturgie. Conférences Saint-Serge LVI Semaine d'Études Liturgiques. Paris 29 juin - 2 juillet 2009, ed. A. Lossky and M. Sodi, Vatican City 2011.

Giraudo C., Eucaristia per la Chiesa. Prospettive teologiche sulleucaristia a partire dalla "lex orandi", Rome-Brescia 1989.

Janicki J., "Modlitwy nad darami," in: Mszał księga życia chrześcijańskiego, ed. B. Nadolski, Poznań 1989, pp. 35-70.

Krakowiak C., "Aklamacje anamnetyczne po konsekracji," in: Modlitwy Eucharystyczne Mszału Rzymskiego. Dzieje - teologia - liturgia, ed. H. J. Sobeczko, Opole 2005, pp. 167-179.

Kunzler M., Liturgia Kościoła, Poznań 1999.

Liturgia eucaristica bizantina, ed. M. B. Artioli, Turin 1988.

Mazza E., Dall'Ultima Cena all'Eucaristia della Chiesa, Bologna 2014.

Mazza E., L'anafora eucaristica. Studi sulle origini, Rome 1992.

Meyer H. B., "Anamnese (5), Liturgisch," in: Lexikon für Theologie und Kirche, ed. W. Kasper et al., vol. 1, Freiburg-Basel-Wien 2009, cols. 592-593.

Miazek J., “Kolekta," in: Mszał księga życia chrześcijańskiego, ed. B. Nadolski, Poznań 1989, pp. 24-33.

Missale Romanum ex decreto Sacrosancti Ecumenici Concilii Vaticani II instauratum auctoritate Pauli PP. VI promulgatum Ioannis Pauli PP. II cura recognitum, editio typica tertia, Vatican City 2002.

Nadolski B., Chwała Ojcu. Doksologie w liturgii, Poznań 1999.

Nadolski B., Leksykon liturgii, Poznań 2006. 
Nowak J., "IV Modlitwa Eucharystyczna," in: Modlitwy Eucharystyczne Mszału Rzymskiego. Dzieje - teologia - liturgia, ed. H. J. Sobeczko, Opole 2005, pp. 235-243.

Nowakowski P., "Anafory - modlitwy eucharystyczne Kościołów Wschodnich," in: Modlitwy Eucharystyczne Mszału Rzymskiego. Dzieje - teologia - liturgia, ed. H. J. Sobeczko, Opole 2005, pp. 7-23.

Olszewski M., "Anamneza w liturgii bizantyjskiej," in: Mszał księga życia chrześcijańskiego, ed. B. Nadolski, Poznań 1989, pp. 391-411.

Prex Eucharistica. Textus e variis liturgiis antiquioribus selecti, ed. A. Hänggi and I. Pahl, Fribourg 1968.

Schaeffler R., "Przypomnienie/Anamneza," in: Leksykon religii. Zjawiska - dzieje - idee, ed. P. Pachciarek, Warsaw 1997, pp. 369-372.

Sobeczko H. J., “Teologiczna treść modlitw pokomunijnych w nowym mszale," in: Mszał ksiegga życia chrześcijańskiego, ed. B. Nadolski, Poznań 1989, pp. 119-134.

Świerzawski W., Dynamiczna "Pamiątka" Pana. Eucharystyczna anamneza Misterium Paschalnego i jego egzystencjalna dynamika, Kraków 1980.

Świerzawski W., “Odo Casel (1886-1948) - życie i dzieło," Ruch Biblijny i Liturgiczny 41 (1988) 2, pp. 89-105.

Trapani V., Memoriale di salvezza. L'anamnesi eucaristica nelle anafore d'Oriente e d'Occidente, Vatican City 2006.

Vinsentin P., "Eucaristia," in: Nuovo Dizionario di Liturgia, ed. D. Sartore and A. M. Triacca, Cinisello Balsamo 1990, pp. 482-508. 